\title{
Iron Deficiency in the Rat: Biochemical Studies of Brain Metabolism
}

\author{
BRUCE MACKLER, ${ }^{(24)}$ RICHARD PERSON, LOUISE R. MILLER, A. R. INAMDAR, AND \\ C. A. FINCH \\ Departments of Pediatrics and Medicine, and Center for Child Development and Mental Retardation, \\ University of Washington, Seattle, Washington, USA
}

\begin{abstract}
Summary
Studies were performed to determine the effects of iron deficiency on brain metabolism in rats. Concentrations of cytochrome pigments, oxidative phosphorylation, and catalase and monoamine oxidase activities in brain tissue were unaffected by iron deficiency. However, activities of aldehyde oxidase, a key enzyme in the pathway of serotonin degradation, were significantly reduced, and concentrations of serotonin and total 5 hydroxyindole compounds were elevated in brain tissue of irondeficient animals. Aldehyde oxidase activities and concentrations of 5-hydroxyindole compounds in brain tissues returned to approximately normal values one week after treatment of iron deficient animals with iron dextran.
\end{abstract}

\section{Speculation}

States of iron deficiency may result in reduction of important iron containing enzymes in brain tissue and altered brain metabolism.

Previously, we have shown that a limited running ability due to iron deficiency in rats results from decreased levels in skeletal muscle mitochondria of $\alpha$-glycerophosphate oxidase, an ironcontaining enzyme which is a component of the terminal electron transport systems (11). Reports of other investigators, summarized in a recent review by Pollitt and Leibel (16) suggests that iron deficiency may in addition adversely affect behavior and learning in animals and man. Since the changes observed in mental function may also result from altered metabolism due to decreased amounts of iron containing enzymes in brain tissue, the present study was undertaken to determine the effects of iron deficiency on the concentrations and activities of important iron containing enzymes in brain and to elucidate the changes in metabolism which may result.

\section{MATERIALS AND METHODS}

Male Sprague-Dawley rats were obtained at 4 weeks of age, 1 week after weaning. The control animals were fed Purina Laboratory Chow (Ralston Purina Company, Inc., St. Louis, MO) containing $282 \mathrm{mg}$ iron $/ \mathrm{kg}$. Rats to be made iron deficient were given a low iron diet (ICN Pharmaceuticals Inc., Life Sciences Group, Cleveland, $\mathrm{OH}$ ) which contained $8 \mathrm{mg}$ iron $/ \mathrm{kg}$. After 1 month on this diet, the hemoglobin concentration of those animals receiving it was determined and studies were performed only on rats with blood hemoglobin concentrations of less than $7 \mathrm{~g} / 100 \mathrm{ml}$. Some of the iron-deficient rats were given weekly intraperitoneal injections of $5 \mathrm{mg}$ iron dextran (Imferon iron, kindly supplied by Lakeside Laboratories, Inc., Milwaukee, WI) beginning at the end of the month on the irondeficient diet, and studies were then performed as described later in the paper. All animals were allowed food and water ad libitum.
Mitochondria were prepared from liver as described previously (13). Mitochondria were prepared from brain as follows. After removal from the calvarium the brains (4-5 $\mathrm{g}$ total) were placed in $20 \mathrm{ml}$ of a solution $\left(0-5^{\circ}\right)$ of $0.22 \mathrm{M}$ mannitol, $0.08 \mathrm{M}$ sucrose, $0.2 \mathrm{mM}$ EDTA, and $5 \mathrm{mM}$ Tris, pH 7.4 (MSET solution). All subsequent procedures were carried out at $0-5^{\circ}$. The brains were rapidly minced with a sharp scissors, rinsed one time with an additional $20 \mathrm{ml}$ cold MSET solution, and suspended in $6 \mathrm{ml}$ MSET solution/g tissue. The suspension was gently homogenized at low speed in a motor-driven Teflon-glass homogenizer and $0.5 \mathrm{ml}$ of a solution containing $1 \mathrm{mg}$ Nagase, $1 \mathrm{mg}$ bovine serum albumin (fraction $\mathrm{V}$ ), and $5 \mathrm{mg} \mathrm{KHCO} / \mathrm{ml}$ was added $/ 6 \mathrm{ml}$ suspension. The suspension was allowed to stand for $2 \mathrm{~min}$ in ice and was again gently homogenized in the Teflon-glass homogenizer. An equal volume of MSET solution was then added and the suspension was centrifuged in a refrigerated centrifuge for $10 \mathrm{~min}$ at $800 \times g$. The supernatant solution was quickly filtered through one layer of coarse cheesecloth and was recentrifuged at $10,000 \times g$ for $10 \mathrm{~min}$. The resulting pellet was gently resuspended in the original volume of MSET solution and was centrifuged for $10 \mathrm{~min}$ at $5,000 \times \mathrm{g}$. The pellet was again suspended in the same volume of MSET solution and centrifuged for $10 \mathrm{~min}$ at $5,000 \times \mathrm{g}$. The resulting mitochondrial pellet was resuspended gently in a small volume of MSET solution (1-1.5 ml) containing $1 \mathrm{mg}$ bovine serum (fraction $\mathrm{V}) / \mathrm{ml}$.

Homogenates were prepared from brain by mincing the tissues with a scissors, rinsing once. with cold MSET solution, and then homogenizing the suspension (iced) at top speed for 5 min in the motor-driven Teflon-glass homogenizer. In studies where broken mitochondria were required, mitochondrial suspensions (iced) were similarly homogenized at top speed for 5 min.

Oxidative phosphorylation was studied polarographically at $25^{\circ}$ with a Clark oxygen electrode (Yellow Springs Instrument Company, Yellow Springs, $\mathrm{OH}$ ) fitted to a closed glass thermostated chamber of 1.6-1.9 ml capacity (Gilson Instrument Company, Madison, WI). Determinations were of two types: ADP:O ratios and respiratory control indexes were determined as described by Chance and Williams (6) and Inamdar et al. (13); and P:O ratios were determined by measurement of ${ }^{33} \mathrm{P}$ incorporation into ATP as described previously. by Mackler et al. (15). Assay systems contained approximately $2 \mathrm{mg}$ mitochondrial protein suspended in $1.7 \mathrm{ml}$ of a solution of $\mathrm{pH} 7.4$ containing $0.3 \mathrm{M}$ mannitol, $0.01 \mathrm{M} \mathrm{KCl}, 0.01 \mathrm{M}$ Tris, and $0.005 \mathrm{M}$ potassium phosphate (MKTP solution).

Difference spectra (dithionite reduced minus dithionite oxidized) of the cytochromes of the mitochondrial respiratory chain were determined by means of a sensitive wavelength-scanning Aminco DW-2 spectrophotometer at $25^{\circ}$ and the concentrations of the cytochromes were calculated by use of the following millimolar extinction coefficients; cytochrome $a+a_{3}$ (605-630 $\mathrm{nm}) ; 24.0$ (20); cytochromes $c+c_{1}(550-540 \mathrm{~nm}), 19.1$ (4); cytochrome $b(562-575 \mathrm{~nm}), 20.0(5)$. 
Catalase activity was determined in brain homogenates as described by Chance and Maehly (7). Aldehyde oxidase, xanthine oxidase and monoamine oxidase activities were determined polarographically at $25^{\circ}$ with a Clark oxygen electrode. For assay, 2-4 mg mitochondrial protein were suspended in 1.7 $\mathrm{ml}$ mannitol solution (MKTP) used for assay of oxidative phosphorylation which contained in addition $10 \mathrm{mM}$ sodium azide, and 2-3 $\mu \mathrm{mol}$ acetaldehyde, hypoxanthine, or serotonin were added to start the reactions for determination of aldehyde, xanthine, or monoamine oxidase activities, respectively. In control studies of monoamine oxidase activity semicarbazide was found to have no effect and, therefore, was not included in the assay mixture.

In some studies aldehyde and xanthine dehydrogenase activities were determined spectrophotometrically at $25^{\circ}$. The assays contained approximately $0.5-1.0 \mathrm{mg}$ mitochondrial protein suspended in $0.8 \mathrm{ml}$ MKTP solution, $0.1 \mathrm{ml} 0.1 \mathrm{M}$ sodium azide solution, and $0.05 \mathrm{ml} 1 \%$ solution of DPN. Reactions were started by addition of $2 \mu \mathrm{mol}$ acetaldehyde or hypoxanthine and the rate of reduction of DPN was recorded at $340 \mathrm{~nm}$.

Concentrations of total 5-hydroxyindole compounds and serotonin in brain homogenates were determined as described by Udenfriend and Weissbach (19), and Curzon and Green (8), respectively. ADP content of standard solutions was determined by the method of Adam (1). Protein was determined by the method of Lowry et al. (14). Hemoglobin was determined as cyanmethemoglobin with standards employed for calibration (Hycel, Inc., Houston, TX). Statistical analyses were performed by standard methods as described by Snedecor and Cochran (17).

Crystalline bovine serum albumin (fraction V), ADP, ATP, rotenone, serotonin, Tris, and EDTA were obtained from Sigma Chemical Co., St. Louis, MO. Nagase was obtained from Biddle Sawer Corp., New York, and ${ }^{33} \mathrm{P}$ was obtained from New England Nuclear, Boston, MA.

\section{RESULTS AND DISCUSSION}

Mitochondria isolated from brain tissue were studied to determine the effects of iron deficiency on first, the concentrations of the various cytochrome pigments associated with termi-

Table 1. Effects of iron deficiency on cytochrome concentrations in mitochondria from brain ${ }^{1}$

$\begin{array}{ccc}\text { Cytochrome } c+c_{1}, & \text { Total cytochrome } b\left(\mathrm{~b}_{\mathrm{T}}\right. & \text { Cytochrome } a+a_{3}, \\ \text { nmol/mg protein } & \left.+\mathrm{b}_{\mathrm{K}}\right), \mathrm{nmol} / \mathrm{mg} \text { protein }\end{array}$
$\mathrm{nmol} / \mathrm{mg}$ protein $\left.\quad+\mathrm{b}_{\mathrm{K}}\right), \mathrm{nmol} / \mathrm{mg}$ protein $\mathrm{nmol} / \mathrm{mg}$ protein

\begin{tabular}{cccccc}
\hline $\begin{array}{c}\text { Control } \\
\text { group }\end{array}$ & $\begin{array}{c}\text { Iron-defi- } \\
\text { cient group }\end{array}$ & $\begin{array}{c}\text { Control } \\
\text { group }\end{array}$ & $\begin{array}{c}\text { Iron-defi- } \\
\text { cient group }\end{array}$ & $\begin{array}{c}\text { Control } \\
\text { group }\end{array}$ & $\begin{array}{c}\text { Iron-defi- } \\
\text { cient group }\end{array}$ \\
\hline 0.46 & 0.48 & 0.25 & 0.30 & 0.27 & 0.28 \\
\pm 0.05 & \pm 0.02 & \pm 0.02 & \pm 0.05 & \pm 0.01 & \pm 0.03 \\
\hline
\end{tabular}

\footnotetext{
${ }^{1}$ The data represent the averages of data from four experiments \pm
} SEM. nal electron transport, and second, on the ability of the preparations to carry out oxidative phosphorylation. Results are shown in Tables 1 and 2. As described in the tables, the cytochrome content of brain mitochondria and their phosphorylation capacity as measured by $\mathrm{P}: \mathrm{O}$ ratios (or ADP:O ratios), rates of ATP formation and respiratory control indexes were unaffected by iron deficiency. Thus brain tissue appears to resemble heart muscle rather than skeletal muscle where the cytochrome content is depleted and oxidative phosphorylation is markedly impaired by iron deficiency (11). Studies were also performed on brain homogenates to determine the effects of iron deficiency on the concentrations and activity of catalase, another heme-containing enzyme. As shown in Table 3, both the specific activity and tissue concentrations of the enzyme were unaffected by iron deficiency.

The effects of iron deficiency on the degradation of serotonin by brain mitochondria were also studied since iron-dependent enzymes are involved in this metabolic pathway (12). Monoamine oxidase, the enzyme which degrades serotonin to 5hydroxyindoleacetaldehyde, was formerly thought to be an iron dependent enzyme $(18,21)$, but recent work now suggests that iron may not be a cofactor (3). However, it is well established that non-heme iron is a catalytically necessary component of aldehyde oxidase (2), the enzyme necessary for final oxidation of 5-hydroxyindoleacetaldehyde to 5-hydroxyindoleacetic acid which is excreted by the cell. As shown in Table 4 , the specific activity and activity per $\mathrm{g}$ brain of aldehyde oxidase were significantly decreased in mitochondrial preparations from irondeficient animals, but monoamine oxidase activities were unaffected. In other experiments, it was found that preparations of brain mitochondria did not contain aldehyde dehydrogenase activity as do liver mitochondria, and reacted only with oxygen as acceptor during acetaldehyde oxidation and not with DPN or cytochrome $c$.

Since Symes et al. (18) have previously reported that monoamine oxidase activity was decreased in liver preparations from iron-deficient rats, it was of interest to also study the effects of iron deficiency on the activities of aldehyde and monoamine oxidase in liver mitochondria. Table 5 shows the results of experiments which demonstrate that the specific activities of

Table 3. Effects of iron deficiency on catalase activity of brain homogenates ${ }^{1}$

\begin{tabular}{lcc}
\hline Animals studied & $\begin{array}{c}\text { Sp act, } \mu \mathrm{mol} \text { peroxide } \\
\text { metabolized/min/mg } \\
\text { protein }\end{array}$ & $\begin{array}{c}\text { Activity/g homogenate, } \\
\mu \mathrm{mol} \text { peroxide metabo- } \\
\text { lized/min/g homogenate }\end{array}$ \\
\hline Control group & $3.3 \pm 0.2$ & $433 \pm 22$ \\
$\begin{array}{c}\text { 4-week iron-de- } \\
\text { ficient group }\end{array}$ & $\begin{array}{l}3.0 \pm 0.2 \\
(P>0.2)\end{array}$ & $\begin{array}{l}412 \pm 15 \\
(P>0.4)\end{array}$ \\
\hline
\end{tabular}

${ }^{1}$ All values represent the averages of data from six separate experiments \pm SEM.

Table 2. Effects of iron deficiency on oxidative phosphorylation in mitochondria from brain ${ }^{1}$

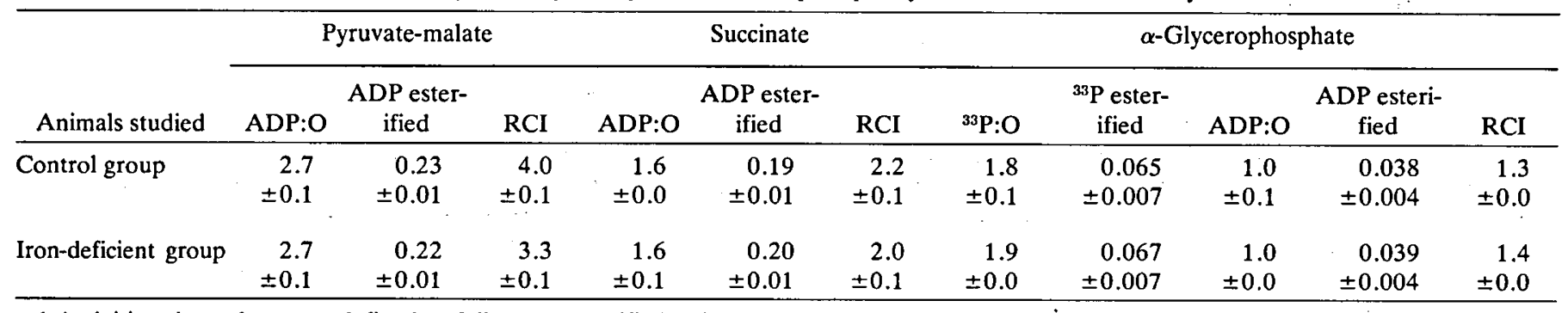

${ }^{1}$ Activities given above are defined as follows: $P$ esterified, micromoles of P. esterified per min per mg protein; ADP esterified, micromoles of ADP phosphorylated per min per mg protein; RCI (respiratory control index) was calculated as the ratio of state 3 rate of oxidation to state 4 rate of oxidation. The data represent averages of data from four separate experiments \pm SEM. 
Table 4. Effects of iron deficiency on monoamine oxidase and aldehyde oxidase activities ${ }^{1}$ of brain mitochondria

\begin{tabular}{|c|c|c|c|c|c|}
\hline \multirow[b]{2}{*}{ Animals studied } & \multicolumn{2}{|c|}{ Monoamine oxidase } & \multicolumn{2}{|c|}{ Aldehyde oxidase } & \multirow{2}{*}{$\begin{array}{c}\text { Mitochondrial protein, } \\
\text { mg/g brain }\end{array}$} \\
\hline & Sp act & Activity/g brain & Sp act & Activity/g brain & \\
\hline $\begin{array}{l}\text { Control group } \\
\text { 4-week iron-deficient group }\end{array}$ & $\begin{array}{c}5.22 \pm 0.38 \\
4.90 \pm 0.21 \\
(P>0.4)\end{array}$ & $\begin{array}{c}12.4 \pm 1.2 \\
12.3 \pm 0.8 \\
(P>0.6)\end{array}$ & $\begin{array}{c}5.99 \pm 0.45 \\
3.94 \pm 0.43 \\
(P<0.01)\end{array}$ & $\begin{array}{c}14.4 \pm 1.6 \\
9.78 \pm 1.20 \\
(P<0.05)\end{array}$ & $\begin{array}{l}2.4 \pm 0.2 \\
2.5 \pm 0.2 \\
(P>0.6)\end{array}$ \\
\hline
\end{tabular}

${ }^{1}$ All values represent the averages of data for 10 or more separate experiments \pm SEM. Specific activity is defined as the $n$ anomoles of substrate (serotonin or acetaldehyde) oxidized per min per $\mathrm{mg}$ mitochondrial protein. Activity per $\mathrm{g}$ brain is defined as nanomoles substrate oxidized per min per $g$ wet tissue.

Table 5. Effects of iron deficiency on aldehyde oxidase and monoamine oxidase activities ${ }^{1}$ in liver mitochondria

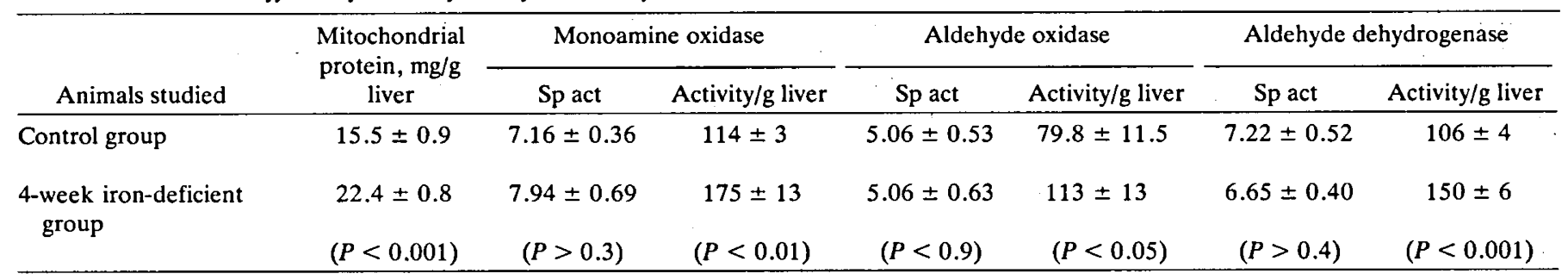

${ }^{1}$ All values represent the averages of data for eight experiments for aldehyde oxidase and mitochondrial protein determinations and four experiments for aldehyde dehydrogenase and monoamine oxidase \pm SEM. Specific activity is defined as the nanomoles of substrate (serotonin or acetaldehyde) oxidized per min per $\mathrm{mg}$ of mitochondrial protein. Activity per $\mathrm{g}$ liver is defined as nanomoles of substrate oxidied per min per $\mathrm{g}$ wet tissue.

Table 6. Effects of iron deficiency on concentrations of total 5 hydroxyindole compounds and serotonin in brain ${ }^{1}$

\begin{tabular}{lcc}
\hline \multicolumn{1}{c}{ Animals studied } & $\begin{array}{c}\text { Total 5-hydroxyin- } \\
\text { doles, } \mu \mathrm{g} / \mathrm{g} \text { brain }\end{array}$ & Serotonin, $\mu \mathrm{g} / \mathrm{g}$ brain \\
\hline Control group & $1.90 \pm 0.07$ & $0.909 \pm 0.040$ \\
$\begin{array}{l}\text { 4-week iron-deficient } \\
\text { group }\end{array}$ & $\begin{array}{c}2.17 \pm 0.08 \\
(P=0.01)\end{array}$ & $\begin{array}{c}1.01 \pm 0.028 \\
(P=0.05)\end{array}$ \\
\hline
\end{tabular}

${ }^{1}$ The values represent the averages of data for 18 separate experiments for concentrations of 5-hydroxyindole compounds and 12 experiments for concentrations of serotonin \pm SEM.

liver mitochondrial aldehyde oxidase (and dehydrogenase) and monoamine oxidase were unaffected by iron deficiency. However, in accord with previous reports by Dallman (9), liver mitochondrial protein was significantly increased in the iron deficient animals, resulting in increased levels of monoamine oxidase and aldehyde oxidase and dehydrogenase activities per g liver tissue.

Following the finding that aldehyde oxidase activity was decreased in brain preparations from iron-deficient rats, studies were performed to determine whether the decrease in enzymatic activity was sufficient to affect the concentrations of serotonin (5-hydroxytryptamine) and other 5-hydroxyindole compounds in brain tissue. As shown in Table 6, tlie concentrations of both serotonin and total 5-hydroxyindole compounds (serotonin, 5hydroxyindoleacetaldehyde, and 5-hydroxyindoleacetic acid) were significantly elevated in brain tissue of iron-deficient animals, suggesting that aldehyde oxidase activity is sufficiently lowered in brain tissue in iron deficiency to be the rate-limiting step in serotonin degradation, thus leading to accumulation of and increased concentrations of serotonin and 5-hydroxyindoleacetaldehyde. In other experiments, iron-deficient rats were given weekly intraperitoneal injections of $5 \mathrm{mg}$ iron dextran and aldehyde oxidase activities and concentrations of total 5-hydroxyindole compounds in brain tissue were determined. As shown in Figure 1, aldehyde oxidase activity increased to approximately control levels after 1 week of iron treatment and, concomitantly, concentrations of total 5-hydroxyindole compounds fell to normal values.

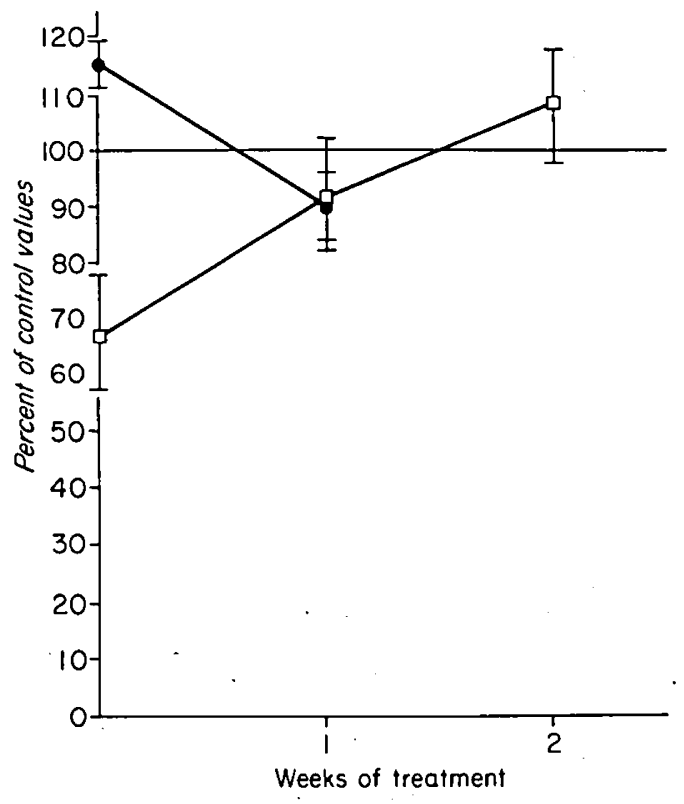

Fig. 1. Effects of treatment with iron dextran on aldehyde oxidase activity and concentrations of 5-hydroxyindole compounds in brain tissue of iron-deficient rats. Aldehyde oxidase activity (micromoles of acetaldehyde oxidized per min per mg protein), $\square-\square$; concentrations of 5-hydroxyindole compounds, $\longrightarrow$.

In conclusion, it would appear possible that some of the symptoms of impaired mental function described previously in iron-deficient animals and human subjects (16) may be related to elevated levels of 5-hydroxyindole compounds in the brain tissue, since serotonin and other tryptaminergic drugs have been found to produce similar symptoms of drowsiness and decreased attentiveness and ability to learn (10). It is of particular interest that symptoms appear to improve markedly in iron-deficient human subjects within 1 week after treatment with iron (io), a period of time in which levels of 5-hydroxyindole compounds in brain tissue of treated iron-deficient rats also decrease to normal as shown earlier in the paper. 


\section{REFERENCES AND NOTES}

1. Adam, H.: Adenosine-5'-diphosphate and adenosine-5'-monophosphate. In: Methods of Enzymatic Analysis, Ed. 1, pp. 573-577 (Academic Press, New York, 1965).

2. Bray, R. C.: Molybdenum Iron-Sulfur Flavin Hydroxylases and Related Enzymes. In: P. D. Boyer: The Enzymes, Vol. 12B, Ed. 3, pp 299-417 (Academic Press, New York, 1975).

3. Bright, H. J., and Porter, D. J. T.: Flavoprotein Oxidases. In: P. D. Boyer: The Enzymes, Vol 12B, Ed. 3, pp. 466-471 (Academic Press, New York, 1975).

4. Chance, B.: Spectra and reaction kinetics of respiratory pigments of homogenized and intact cells. Nature, 169: 215 (1952).

5. Chance, B., and Williams, G. R.: Respiratory enzymes in oxidative phosphorylation. II. Difference spectra. J. Biol. Chem., 217: 395 (1955).

6. Chance B., and Williams, G. R.: Respiratory enzymes in oxidative phosphorylation. I. Kinetics of oxygen utilization. J. Biol. Chem., 217: 383 (1955)

7. Chance, B., and Maehly, A. C.: Assay of catalases and peroxidases. II. Methods for crude cell extracts. In: S. P. Colowick and N. O. Kaplan: Methods in Enzymology, Vol. II, pp. 768-769 (Academic Press, New York, 1955).

8. Curzon, G., and Green, A. R.: Rapid method for the determination of 5hydroxytryptamine and 5-hydroxyindoleacetic acid in small regions of rat brain. Brit. J. Pharmacol., 39: 653 (1970).

9. Dallman, P. R.: Tissue Effects of Iron Deficiency. In: A. Jacobs and M. Worwood: Iron and Biochemistry and Medicine, pp. 437-472 (Academic Press, New York, 1974).

10. Douglas, W. W: Histamine and Antihistamines; 5-Hydroxytryptamine and Antagonists. In: L. S. Goodman and A. Gilman: The Pharmacological Basis of Therapeutics, Ed. 5, pp. 613-622 (MacMillan Publishing Co., New York, 1975).

11. Finch, C. A., Miller, L. R., Inamdar, A. R., Person, R., Seiler, K., and Mackler, B.: Iron deficiency in the rat: Physiological and biochemical studies of muscle dysfunction. J. Clin. Invest., 58: 447 (1976).

12, Greenburg, D. M: Carbon catabolism of amino acids. In: D. M. Greenburg:
Metabolic Pathways, Amino Acids and Tetrapyrroles, Vol. III, Ed. 3, p. 176 (Academic Press, New York, 1969).

13. Inamdar, A. R., Person, R., Kohnen, P., Duncan, H., and Mackler, B.: Effect of age on oxidative phosphorylation in tissues of hamsters. J. Gerontol., 29: 638 (1974).

14. Lowry, O. H., Rosebrough N. J., Farr, A. L., and Randall, R. J.: Protein measurement with the Folin phenol reagent. J. Biol. Chem., 193: 265 (1951).

15. Mackler, B., Haynes, B., Inamdar, A. R., Pedegana, L. R., Hall, J. G., and Cohen, M. M., Jr.: Oxidative energy deficiency. II. Human achondroplasia. Arch Biochem Biophys., 159: 885 (1973).

16. Pollitt, E. and Leibel R. L.: Iron deficiency and behavior. J. Pediat., 88: 372 (1976).

17. Snedecor, G. W. and Cochran, W. G.: Statistical Methods, Ed. 6, pp. 258298 (Iowa State University Press, Ames, Iowa, 1974).

18. Symes, A. L., Sourkes, T. L., Youdim, M. B. H., Gregoriadis, G., and Birnbaum, H.: Decreased monoamine oxidase activity in liver of irondeficient rats. Can. J. Biochem, 47: 999 (1969).

19. Udenfriend, S., and Weissbach, H.: 5-Hydroxytryptophan and derivatives: Determination of total 5-hydroxyindoles. In: S. P. Colowick and N. O. Kaplan: Methods in Enzymology, Vol. VI, pp 601-602 (Academic Press, New York, 1963).

20. Van Gelder, B. F.: On cytochrome $c$ oxidase. I. The extinction coefficients of cytochrome $a$ and $a_{3}$. Biochim. Biophys. Acta, 118: 36 (1966).

21. Youdim, M. B. H., and Sourkes, T. L.: Properties of purified, soluble monoamine oxidase. Can. J. Biochem., 44: 1397 (1966).

22. The present address of A. R. Inamdar is: Department of Biochemistry, Indian Institute of Science, Bangalore-12, India.

23. This research was supported in part by Grants GM-23006, HD-05961, HL 06242, and HD-02274 from the NIH.

24. Requests for reprints should be addressed to: Bruce Mackler, M.D., Department of Pediatrics, RD-20, School of Medicine, University of Washington, Seattle, WA 98195 (USA).

25. Received for publication March 28, 1977.

26. Accepted for publication June $28,1977$. 